\title{
A ADMISSIBILIDADE DOS MEIOS DE PROVA ILÍCITOS NO PROCESSO CIVIL: UMA ANÁLISE A PARTIR DA CONFORMAÇÃO CONTEMPORÂNEA DOS PODERES INSTRUTÓRIOS DO JUIZ E DA TÉCNICA DE PONDERAÇÃO DO ART. 489, \$1 $1^{\circ}$ DO CPC/2015
}

\author{
THE ADMISSIBILITY OF ILLICIT EVIDENCE IN CIVIL PROCEEDINGS: AN ANALYSIS \\ BASED ON THE CONTEMPORARY CONFORMATION OF THE JUDGE'S INSTRUCTIVE \\ POWERS AND THE CONSIDERATION TECHNIQUE OF ART. 489, § 1 OF CPC / 2015
}

\section{Trícia Navarro Xavier Cabral}

Pós-Doutora em Processo Civil pela USP. Doutora em Direito Processual pela UERJ. Mestre em Direito Processual pela UFES. Professora do PPGDIR da UFES. Membro da Comissão Acadêmica do FONAMEC. Membro do IBDP. Juíza de Direito do Estado do Espírito Santo. Professora da Universidade Federal do Espírito Santo.

E-mail: tricianavarro@hotmail.com

\section{Frederico Ivens Miná Arruda de Carvalho}

Mestrando em Direito Processual pela Universidade Federal do Espírito Santo. Juiz de Direito do Estado do Espírito Santo.

E-mail: frederico.ivens@gmail.com

Recebido em: 27/08/2019

Aprovado em: 07/05/2020

\begin{abstract}
RESUMO: O artigo tem por finalidade a análise da questão referente à admissibilidade dos meios de prova ilícitos no processo civil a partir do paradigma do Código de 2015, buscando identificar em que medida o diploma normativo alterou a dinâmica de tal instituto. Adotou-se o método descritivo-exploratório por meio de revisão bibliográfica sobre o caráter fundamental do direito à prova; as correntes clássicas e contemporâneas sobre o conceito e admissibilidade da prova ilícita e a fundamentação idônea das decisões sobre a matéria, investigando-se ademais a contribuição da técnica de ponderação trazida pelo art.489, § $2^{\circ}$ do CPC/2015 para sua concretização.
\end{abstract}

Palavras-chave: Processo Civil; Prova ilícita; Admissibilidade; Fundamentação; Ponderação.

\begin{abstract}
The purpose of the article is to analyze the question regarding the admissibility of illicit means of evidence in civil proceedings based on the 2015 Code paradigm, seeking to identify to what extent the normative diploma changed the dynamics of such institute. The descriptiveexploratory method was adopted through bibliographic review on the fundamental character of the right to the proof; the classic and contemporary trends on the concept and admissibility of illicit evidence and the proper reasoning for decisions on the matter, further investigating the contribution of the weighting technique brought by art.489, § 2 of CPC / 2015 to its implementation.
\end{abstract}

Keywords: Civil Procedure. Illegal means of evidence. Admissibility. Rationale. Consideration 
technique.

SUMÁRIO: Introdução. 1 Da prova como direito fundamental de porte implícito e pressuposto de uma decisão justa. 2 Dos poderes instrutórios do juiz no paradigma do CPC/2015: do fundamento publicista à cooperação processual. 3 Dos meios de prova ilícitos e sua excepcional admissibilidade no processo civil. 4 Da técnica de ponderação no CPC/2015 (art.489, § 2o) e sua aplicação na hipótese de excepcional admissão dos meios de prova ilícitos. Conclusões. Referências

\section{INTRODUÇÃO}

O presente trabalho intenta averiguar a admissibilidade dos meios ilícitos de prova no processo civil contemporâneo, a partir do paradigma jurídico-estatal ${ }^{1}$ do Código de Processo Civil de 2015.

A questão posta a estudo enseja debates doutrinários que antecedem a promulgação da Constituição Federal de 1988, atribuíveis à enunciação de preceitos aparentemente antitéticos em seu texto, sendo, ademais, objeto de controvérsia na jurisprudência.

Tal dissenso guarda ao longo do tempo nítido vínculo com a visão atribuída aos institutos do direito à prova e da conformação dos poderes instrutórios do juiz no sistema vigente.

De outro lado, percebe-se que o diploma vigente incorporou nitidamente os valores trazidos pelo texto constitucional, incorporados ao processo, que passa a ser declaradamente destinado à solução adequada dos litígios, a ser alcançada por meio de valores como justiça, igualdade, participação, efetividade e segurança, convolando-se, conforme registro de Sérgio Gilberto Porto $^{2}$, em "método de realização da justiça material através da supremacia de valores com assento constitucional".

Nesta linha, a revisão bibliográfica efetuada de destina à análise da matéria à luz dos valores e técnicas trazidas pelo CPC de 2015, visando a apuração pormenorizada dos contornos e limites do direito das partes à prova e dos poderes instrutórios do magistrado; dos critérios para a admissão dos meios de prova ilícitos e da fundamentação da decisão judicial que aprecia a tal matéria, buscando contribuir para o debate sobre o tema sobremaneira relevante.

\section{DA PROVA COMO DIREITO FUNDAMENTAL DE PORTE IMPLÍCITO E PRESSUPOSTO DE UMA DECISÃO JUSTA}

A prestação da tutela jurisdicional enseja a aplicação de normas a fatos, em relação aos quais o adequado conhecimento é imprescindível para um julgamento de qualidade ${ }^{3}$, sendo, então, objeto de reconstrução no ambiente do processo, no qual se busca o alcance da verdade possível, a par da utópica reconstrução da integralidade dos eventos, de modo que o convencimento do magistrado venha a contemplar o máximo de coincidência e compatibilidade com o direito do litigante, aplicando-se, assim, a justiça esperada pelos jurisdicionados ${ }^{4}$.

Desta forma, os institutos "prova", "verdade" e "justiça" guardam nítida ligação, pois, sendo o direito exprimido por normas, que incidem em fatos hipoteticamente previstos, a idônea

1 NUNES, Dierle. BAHIA, Alexandre. Pedron, Flávio Quinaud. Teoria geral do processo. Salvador: JusPodivm, 2020. p.82-83.

2 PORTO, Sérgio Gilberto. Processo civil contemporâneo: elementos, ideologia e perspectivas. Salvador: JusPodivm, 2018. p.22-24.

3 BARBOSA MOREIRA, José Carlos. O juiz e a prova. Revista de Processo, São Paulo, v. 35/1984, p.178-184, jul./set. 1984. p.179.

4 CABRAL, Trícia Navarro Xavier. Poderes instrutórios do juiz no processo de conhecimento. Brasília: Gazeta Jurídica, 2012. p.09.

Revista de Direito Brasileira | Florianólopis, SC | v. 25 | n. 10 | p. 366-384 | Jan./Abr. 2020 
averiguação sobre a ocorrência destes é, como sói, fundamental para que se determine a acertada incidência e a produção de efeitos. ${ }^{5}$

Nesta toada, conforme pontua Marcelo Abelha ${ }^{6}$, correta averiguação dos fatos contribui de maneira decisiva a legitimação da coisa julgada emanada do processo, sendo curial que sua visão transcenda a tradicional ótica retrospectiva (comprovação dos fatos ocorridos no pretérito), para ser conformada, também, de maneira prospectiva.

Deveras, se a prestação jurisdicional se destina à formação de uma coisa julgada, tendente ao alcance dos escopos do processo, a justiça (e consequente legitimidade democrática) e legalidade de tal pronunciamento do Estado-Juiz não pode prescindir de uma adequada verificação dos fatos relevantes para sua cognição sobre o litígio instaurado.

Conforme Michele Taruffo ${ }^{7}$ de nada adiantaria a observância das garantias processuais (processo justo) e a adequada interpretação e aplicação da norma, se incidentes sobre fatos apurados de maneira equivocada, de modo que "a afirmação da verdade do fato que se qualifica como juridicamente relevante conforme a norma aplicada é condição necessária para a correta aplicação da norma no caso concreto, segundo o princípio da legalidade" ${ }^{\text {. }}$.

Consiste, assim, conforme sintetiza Rogéria Dotti Dória9, a verdade no "complemento que confere valor, importância e respeito à decisão judicial”.

Nesta linha, em dispositivo sem correspondente no diploma anterior, o Código de Processo Civil preocupou-se, no seu art. $6^{\circ}$ com a obtenção de uma decisão de mérito dotada do atributo "justa", ao concitar todos os sujeitos do processo a "cooperar entre si para que se obtenha em tempo razoável uma decisão de mérito justa e efetiva", contemplando assim um valoroso princípio $^{10}$ que estabelece deveres de conduta para o magistrado e partes, dinamizando o funcionamento do processo contemporâneo ${ }^{11}$, marcado pela atuação colaborativa das partes e do juízo para os aportes do acervo probatório.

Como corolário do princípio do devido processo legal, o direito de defesa e a garantia do contraditório dos litigantes não se circunscrevem às faculdades de postular, contestar, excepcionar

5 SEGUNDO, Hugo de Brito Machado. Os Poderes Instrutórios do Juiz no Novo CPC. In: MACÊDO, Lucas Buril de. PEIXOTO, Ravi. FREIRE, Alexandre. Provas. Coleção novo CPC doutrina selecionada. vol. 3.2 ed, Salvador: JusPodivm, 2016. p.329.

6 "A prova, portanto, é um desses instrumentos decisivos no alcance da paz social. Ora, se a coisa julgada é fenômeno político de estabilidade e segurança jurídica, fruto de uma 'verdade jurídica' que muitas vezes não corresponde à realidade dos fatos, e, às vezes por isso, se diz que é fenômeno criador de direitos, não se pode negar que a prova no processo tem a força capital, qual seja a de permitir que se alcance, com a convicção que dela resulta, um fenômeno que legitima a estabilização de uma decisão justa em relação ao fato de se dar razão a quem realmente a possui. De fato, não é a coisa julgada que traz a paz social. Além do escopo político que pode existir, é certo que a coisa julgada só será legítima, no sentido de alcançar o escopo social do processo, se for assentada em elementos de convicção que sejam os mais próximos da realidade histórica conflituosa levada ao Estado-Juiz. Quando isso ocorre há, por assim dizer, um reconhecimento da sociedade e dos próprios litigantes, independentemente de serem vencidos ou vencedores, porque sabem, à evidência das provas, que se fez justiça". ABELHA, Marcelo. Manual de direito processual civil. 6. ed. Rio de Janeiro: Forense, 2016. p.538.

7 TARUFFO, Michele. Uma simples verdade: o juiz e a construção dos fatos. tradução de Vitor de Paula Ramos. São Paulo: Marcial Pons, 2016. p.141-142.

8 TARUFFO, Michele. As Verdades Judiciais. tradução de José Teisheiner. Ensaios sobre o Processo Civil: escritos sobre processo e justiça. Porto Alegre: Livraria do Advogado. 2017. p.183.

9 DORIA, Rogéria Dotti. O Direito à prova e a busca da verdade material. In: NEVES, Daniel Amorim Assumpção (coord). Provas: aspectos atuais do direito probatório, p.324-327, São Paulo: Método, 2009. p.333-334.

10 Assevera Jorge Luiz Reis Fernandes que a ideia da cooperação como princípio se justifica pois esta, de fato: "promove um estado de coisas, especialmente em relação às garantias constitucionais (devido processo legal, processo justo, solidariedade, democracia, boa-fé; fundamentação participada; contraditório, dentre outros" sendo, ademais, dotada de sanções para as hipóteses de descumprimento, como multas, penalidade por crime de desobediência e nulidade processual. FERNANDES, Jorge Luiz Reis. Cooperação: os deveres do juiz e das partes no novo código de processo civil. Belo Horizonte: Letramento/Casa do Direito, 2017, p.173.

11 MITIDIERO, Daniel. A colaboração como norma fundamental no novo processo civil brasileiro. Revista do Advogado: o novo código de processo civil. São Paulo, n. 126, 2015. p.47.

Revista de Direito Brasileira | Florianólopis, SC | v. 25 | n. 10 | p. 366-384 | Jan./Abr. 2020 
ou reconvir, contemplando, ademais, o amplo acesso aos meios de prova aptos à demonstração das alegações de fato, que devem ser admitidos, produzidos e valorados.

Consiste, portanto, o direito à prova em uma norma-princípio de porte implícito ${ }^{12}$, da qual emana o direito das partes de produzir os meios que permitam formar a convicção do julgador no sentido de que as alegações sobre fatos controvertidos correspondem à realidade histórica ${ }^{13}$, e então extrair as consequências jurídicas.

Portanto, conforme registra José Roberto dos Santos Bedaque ${ }^{14}$ : “o contraditório é efetivo e a defesa ampla quando a parte tem o poder de utilizar todos os meios de prova possíveis e adequados à reconstrução dos fatos que constituem, modificam ou extinguem o direito afirmado", de modo que o direito à prova configura um componente inafastável do contraditório e da ampla defesa, que deve ser analisado à luz do acesso à proteção jurisdicional.

Nesta linha, verifica-se que o Código de Processo Civil vigente procedeu à infraconstitucionalização de garantias processuais ${ }^{15}$, conquanto incorporadas às normas fundamentais do diploma de 2015, que, sob o influxo de valores constitucionais (art. $1^{\circ}$ ); atento aos fins sociais, bem comum e promoção da dignidade humana (art. $9^{\circ}$ ); na busca do acesso à solução adequada dos litígios $\left(\operatorname{art} .3^{\circ}\right)$; tratou de assegurar o contraditório, a ampla defesa e o dever de fundamentação idônea das decisões ( $\operatorname{art} .9^{\circ}, 10$ e 11$)$.

Por fim, o diploma enunciou que as partes se encontram investidas no direito de empregar todos os meios de prova legais e moralmente legítimos, ainda que atípicos, para provar a verdade dos fatos em que se funda o pedido e influir de forma eficaz na convicção do juiz (CPC, art. 369), dispensando-se sua tipicidade para a admissão no processo. ${ }^{16}$

Destarte, emerge do CPC/2015 a imposição de que deve ser assegurado às partes o mais amplo acesso aos meios de prova legais que se revelem necessários, úteis e praticáveis à verificação de fatos relevantes, que não devem sofrer limitações injustificadas, sendo o critério para seu aferimento, o juízo de proporcionalidade previsto no art. 370 do código de 2015.

Assim, conforme asseverado em comentários de Gisele Santos Fernandes Góes à enunciação do art. 130 do Código de 1973, repristinado no dispositivo em epígrafe, ao prever que o juiz determinará as provas necessárias e indeferirá as diligências inúteis ou protelatórias, o legislador de 1973 - e, dada a repristinação do texto, o de 2015 - contemplou valorativamente os três elementos da proporcionalidade.

Com efeito, infere-se a menção ao componente necessidade, ao sinalizar que devem ser deferidos os meios de prova necessários à instrução do processo; à adequação, no momento em que se refuta o deferimento de diligências inúteis, consignando a exigência de propriedade do meio de prova escolhido, que deve se revelar pertinente para o descortinamento de fato relevante e controvertido; e, por fim, à proporcionalidade em sentido estrito, ao vedar meios de prova protelatórios, que se revelem excessivos e causem desequilíbrio na relação entre as partes. ${ }^{17}$

Firmada tal premissa, cumpre estudar em que medida se delineiam os poderes instrutórios do juízo no paradigma normativo do CPC/2015.

12 GÓES, Gisele Santos Fernandes. Cotejo entre o direito à prova e a proibição de provas obtidas por meios ilícitos. In: FUX. Luiz. NERY JR. Nelson. WAMBIER. Teresa Arruda Alvim (coord). Processo e constituição. Estudos em homenagem ao Professor José Carlos Barbosa Moreira. São Paulo: Revista dos Tribunais, 2006. p.953.

13 REICHELT, Luis Alberto. O direito fundamental à prova e os poderes instrutórios do juiz. Revista de Processo, São Paulo, vol. 281/2018, p. 171-185, jul./2018. p.172.

14 BEDAQUE, José Roberto dos Santos. Garantia da amplitude de produção probatória. In: CRUZ E TUCCI, José Rogério (coord). Garantias constitucionais do processo civil. São Paulo: Revista dos Tribunais, 1999. p.168-169.

15 PORTO, Sérgio Gilberto. Processo civil contemporâneo: elementos, ideologia e perspectivas. Salvador: JusPodivim, 2018. p.55.

16 MARINONI, Luiz Guilherme. ARENHART, Sérgio Cruz. Prova e convicção. 3 ed. São Paulo: Revista dos Tribunais, 2018. p.290.

17 GÓES, Gisele Santos Fernandes. Cotejo entre o direito à prova e a proibição de provas obtidas por meio ilícito. In: FUX, Luiz. NERY JR, Nelson. WAMBIER, Teresa Arruda Alvin. Processo e constituição: estudos em homenagem ao professor José Carlos Barbosa Moreira. São Paulo: Revista dos Tribunais, 2006, p.952-958. p.953.

Revista de Direito Brasileira | Florianólopis, SC | v. 25 | n. 10 | p. 366-384 | Jan./Abr. 2020 


\section{DOS PODERES INSTRUTÓRIOS DO JUIZ NO PARADIGMA DO CPC/2015: DO FUNDAMENTO PUBLICISTA À COOPERAÇÃO PROCESSUAL}

Com o advento da democracia social operou-se uma evolução no Estado e no Direito, de modo que se intensificou a participação do Poder Público no seio social, e, como consequência, de seu órgão (juiz) no ambiente do processo. ${ }^{18}$

Desta forma, não bastava mais ao Estado-Juiz a preocupação adstrita ao formal cumprimento das regras do jogo, abandonando o processo e, especificamente, sua instrução à sorte que as partes lhe conferirem, encontrando-se este investido do verdadeiro dever de zelo para que seja o processo justo e apto a permitir uma adequada verificação dos fatos, a participação das partes em um contraditório efetivo, de modo a propiciar a justa aplicação das normas e a efetividade da tutela dos direitos, em equilíbrio com a liberdade de regramento das partes. ${ }^{19}$

Os poderes instrutórios do juízo encontram, tradicionalmente, lastro nos três pilares publicísticos da busca da igualdade substancial, dentro da relação jurídica processual em que exista uma efetiva paridade de armas entre as partes; intento de que seja reconstruída uma verdade processual mais compatível com a realidade possível; e alcance das finalidades da jurisdição, que transcendem os interesses dos litigantes. ${ }^{20}$

Assim, conforme pontua José Roberto dos Santos Bedaque ${ }^{21}$ em clássica obra sobre a matéria, o protagonismo do magistrado na fase instrutória corresponde a elemento indissociável da efetividade processual, pois o acesso à ordem jurídica justa pressupõe a garantia de ampla produção probatória às partes e a participação do juiz como sujeito interessado no contraditório efetivo e equilibrado e na justiça das decisões.

Nesta linha, malgrado a priori a enunciação quanto aos poderes instrutórios do juiz no CPC/2015 (art.370) tenha reproduzido a redação de dispositivo do diploma anterior (art. 130 do CPC/73), revela-se curial uma leitura sob o prisma da ideologia materializada nas normas fundamentais da lei posterior ${ }^{22}$, do que se infere que a partir do mesmo enunciado prescritivo emana uma proposição e, por conseguinte, norma jurídica distinta.

Com efeito, nota marcante do Código de 2015 reside no redimensionamento da atuação dos sujeitos processuais, que conduz a um equilíbrio na condução do processo entre os expressivos poderes do magistrado e a participação das partes, tendo por prisma a cooperação entre estes. ${ }^{23}$

Portanto, ao concitar os sujeitos processuais a "cooperar entre si para que se obtenha, em tempo razoável, decisão de mérito justa e efetiva", o CPC/2015 estabelece uma releitura dos papéis,

18 MARINONI, Luiz Guilherme. ARENHART, Sérgio Cruz. MITIDIERO, Daniel. Novo curso de processo civil: teoria do processo civil. vol. 1. 3 ed. São Paulo: Revista dos Tribunais, 2017. p. 456-457.

19 CABRAL, Trícia Navarro Xavier. Limites da liberdade processual. Indaituba: Foco, 2019. p.25-26.

20 CABRAL, Trícia Navarro Xavier. Poderes instrutórios do juiz no processo de conhecimento. Brasília: Gazeta Jurídica, 2012. p.14.

21 BEDAQUE, José Roberto dos Santos. Poderes instrutórios do juiz. 7 ed. São Paulo: Revista dos Tribunais, 2013. p. $27 / 28$.

22 GODINHO, Robson Renault. Reflexões sobre os poderes instrutórios do juiz. In: MACÊDO, Lucas Buril de. PEIXOTO, Ravi. FREIRE, Alexandre. Provas. (Coleção novo CPC doutrina selecionada. vol. 3. 2 ed, Salvador: JusPodivm, p.343-368, 2016. p.364.

23 "Entretanto, com a reforma processual de 2015, muda-se diametralmente a perspectiva quanto ao comportamento dos sujeitos processuais, de modo a exigir também uma alteração do foco de interesse da comunidade jurídica. Destarte, a atuação dos sujeitos processuais foi redimensionada, trazendo maior equilíbrio na condução do processo. De um lado, os juízes tiveram seus poderes, deveres e responsabilidades ampliados, como forma de garantir mais efetividade às decisões judiciais. Por outro lado, prestigiou-se a liberdade das partes dentro do processo, permitindo ampla disponibilidade sobre o direito material, sobre as situações jurídicas processuais e ainda sobre o próprio procedimento. Assim, buscou o legislador harmonizar o protagonismo do juiz e a participação das partes no processo, estabelecendo um modo cooperativo de atuação, em prol da efetividade e da legitimidade da prestação da tutela jurisdicional". CABRAL, Trícia Navarro Xavier. Limites da liberdade processual. Indaiatuba: Foco, 2020.p.02.

Revista de Direito Brasileira | Florianólopis, SC | v. 25 | n. 10 | p. 366-384 | Jan./Abr. 2020 
poderes, faculdades e deveres do magistrado ${ }^{24}$, modificando os fundamentos e, sobretudo, a forma de exercício dos seus poderes instrutórios.

Desta forma, dentro do modelo vigente de processo, caberá ao magistrado, após provocação do interessado, manter constante diálogo com as partes, atento aos deveres de lealdade, esclarecimento e proteção, de modo a buscar, prioritariamente, uma solução consensual para o conflito (CPC, art. $3^{\circ}, 334$ e 139, V).

Ato contínuo, não sendo esta solução negociada possível, conduzir, com o auxílio recíproco dos litigantes, uma instrução ampla e democrática, que possibilite a estes efetiva influência no pronunciamento jurisdicional, proferido para, então, em posição assimétrica, conquanto ato de poder ${ }^{25}$, oportunidade na qual, sob pena de nulidade, deverá enfrentar todos os argumentos (leia-se fundamentos) deduzidos no processo e capazes, em tese, de infirmar a conclusão adotada (art.489, $§ 1^{\circ}$, inciso IV do CPC/15).

Desta forma, certo é que a iniciativa probatória do magistrado corresponde a um ato de concreta cooperação com o alcance da decisão de mérito justa e efetiva em tempo razoável, posto como, com o exercício destes, tendencialmente a instrução processual se revestirá de eficiência, possibilitando a maior apuração dos fatos da forma menos onerosa e no menor tempo possível.

Trata-se, assim, de um poder-dever, eis que estritamente instrumental ao alcance da jurisdição, por meio de pronunciamento justo, conquanto identificado com a correta verificação dos fatos relevantes, e apto, eis que manifestação de uma democracia deliberativa-discursiva ${ }^{26}$, ao alcance dos escopos social (pacificando e educando com uma decisão revestida de legitimidade e, portanto, aceita pelas partes); jurídico (reafirmando a vigência do direito objetivo, ante a identificação precisa dos fatos em que incide) e político (afirmando a legitimidade da atuação estatal), fruto de uma comunidade de trabalho com as partes que lhe empresta legitimidade democrática.

Nesta linha, é pertinente o registro de que o Código de Processo Civil de 2015 previu de maneira expressa a extensão dos poderes instrutórios à esfera recursal, tratando no art.932, I dos poderes do relator quanto à direção e ordenamento do recurso "inclusive em relação à produção de prova" e contemplando, conforme entendimento de Luciano Souto Dias ${ }^{27}$, o procedimento a ser adotado, por meio da delegação dos atos instrutórios à primeira instância ou colheita perante o próprio tribunal (art.938, $\S 3^{\circ}$ ).

Portanto, fundado no seu convencimento, deve o magistrado conduzir ativamente a instrução do processo, que há se amoldar à concretude dos fatos, de modo que, em um ambiente cooperativo e igualitário e sob contraditório participativo, seja alcançada uma solução legitimada para o conflito e em tempo razoável, sendo construída, em diálogo e cooperação com as partes, a instrução necessária ao descortinamento mais completo e eficiente possível dos fatos controvertidos.

Nesta toada, tradicionalmente a utilização dos poderes instrutórios do juiz pode ensejar a ampliação do acervo probatório, por meio da determinação, ex officio, da produção de meios de prova não indicados partes, tal como, tipicamente, na realização de perícia; comparecimento pessoal das partes para serem interrogadas sobre os fatos da causa (CPC, art. 139, VIII); exibição

24 ZANETI JR, Hermes. O princípio da cooperação e o código de processo civil: cooperação para o processo. In: Processo civil contemporâneo: homenagem aos 80 anos do Professor Humberto Theodoro Júnior, organização Edgard Audomar Marx Neto [et al.] Rio de Janeiro, Forense, p.142-156, 2018. p. 142-143.

25 DEXHEIMER, Vanessa Grazziotin. Atuação do juiz na condução do processo civil no estado constitucional. In: MITIDIERO, Daniel (coord). O processo civil no estado constitucional. Salvador: JusPodivm, 2012, p. 481-548. p.509.

26 PIMENTA, Henrique de Souza. A cooperação no CPC-2015: colaboração, comparticipação ou cooperação para o processo? Dissertação de Mestrado (Mestrado em Direito Processual) - Universidade Federal do Espirito Santo, Centro de Ciências Jurídicas e Econômicas, 2018. p.84-87.

27 DIAS, Luciano Souto. Poderes instrutórios do julgador na fase recursal do processo civil: em busca da verdade. Salvador: JusPodivm, 2018. p.208.

Revista de Direito Brasileira | Florianólopis, SC | v. 25 | n. 10 | p. 366-384 | Jan./Abr. 2020 
de documentos; inspeção em pessoas ou coisas (CPC, art.481); oitiva de testemunhas referidas ou a acareações (art.461 do CPC) e de outros meios de prova atípicos.

Pode, ademais, implicar na reorganização do procedimento instrutório abstratamente previsto de modo a ajustá-lo às particularidades dos autos, por meio da alteração na ordem de produção dos meios de prova (CPC, art. 139, VI) e redistribuição dinâmica do ônus da prova (art.373, § $1^{\circ}$ do CPC), nas hipóteses em que o quadro fático se amolde a autorização legislativa ou se identificado que, as peculiaridades da causa indicarem a impossibilidade ou excessiva dificuldade de cumprimento dos encargos probatórios da maneira ordinária - e desde que não implique em imposição impossível ou excessivamente difícil (prova diabólica).

Por fim, a utilização dos poderes instrutórios pode conduzir ao abreviamento do acervo probatório, com a dispensa da produção de meios de prova supérfluos e o julgamento antecipado do mérito (art. 355) ou parcial de mérito (art.356, I e II, CPC/15). ${ }^{28}$

No exercício de tais poderes são objeto de deliberação quatro matérias, em ordem consecutiva: admissibilidade; relevância; produção e valoração dos meios de prova. ${ }^{29}$.

Inicialmente, o cotejo quanto à admissibilidade dos meios de prova implica em que, antes de qualquer digressão sobre sua necessidade concreta para o processo, seja verificado sua conformidade com as disposições legais, que conduz assim ao seu cabimento.

Posteriormente, pressuposta a identificação que os meios de prova são cabíveis, cumpre verificar sua relevância, conquanto necessários ao esclarecimento de fatos relevantes e controvertidos nos autos.

Firmadas as premissas quanto ao cabimento e admissibilidade dos meios de prova, cumpre deliberar sobre sua produção, como, tipicamente no CPC/2015, sobre o momento de juntada de documentos (art.435), calendário para a prova pericial (art.367, $\S 8^{\circ}$ e art. 465) e até a inversão da ordem dos atos (art.139, VI).

Por fim, colhidos os meios de prova, cumpre decidir sobre sua valoração, dentro de critérios de racionalidade e legitimidade, após o debate com as partes às quais é assegurado o exercício da dimensão substancial do contraditório.

Destarte, os poderes instrutórios do juízo encontram nova conformação democrática no processo contemporâneo, harmonizando-se com a liberdade processual das partes por meio da cooperação que implica em deveres recíprocos e constante diálogo, o que conduz a uma releitura dos meandros da admissibilidade dos meios de prova ilícitos.

\section{DOS MEIOS DE PROVA ILÍCITOS E SUA EXCEPCIONAL ADMISSIBILIDADE NO PROCESSO CIVIL}

A tradicional classificação de Pietro Nuvolone adotada, dentre outras, pelas obras de Ada Pellegrini Grinover ${ }^{30}$ e Luiz Francisco Torquato Avolio ${ }^{31}$ distingue, dentro do gênero provas vedadas, as espécies ilícita e ilegítima, referentes, respectivamente, aos meios de prova colhidos com violação a normas de direito processual e de direito material.

Desta divisão emerge a concepção tradicional de que as provas ilícitas têm sua produção em uma seara pré ou extraprocessual, ao passo em que as ilegítimas são, necessariamente, endoprocessuais, posto como produzidas, com violação, no ambiente do processo.

28 CABRAL, Trícia Navarro Xavier. Poderes instrutórios do juiz no processo de conhecimento. Brasília: Gazeta Jurídica, 2012. p.76.

29 REICHELT, Luis Alberto. O Direito Fundamental à Prova e os Poderes Instrutórios do Juiz. Revista de Processo, São Paulo, São Paulo, vol. 281/2018, jul./2018. p.171-185.

30 GRINOVER, Ada Pellegrini. As provas ilícitas na constituição. Processo em evolução. Rio de Janeiro: Forense Universitária, 1996. p.46-47.

31 AVOLIO, Luiz Francisco Torquato. Provas ilícitas: interceptações telefônicas, ambientais e gravações clandestinas. 6 ed. São Paulo: Revista dos Tribunais, 2015. p.50/51.

Revista de Direito Brasileira | Florianólopis, SC | v. 25 | n. 10 | p. 366-384 | Jan./Abr. 2020 
Entende-se, ademais, que as sanções para as provas ilegítimas são previstas no ordenamento processual, por meio dos esquemas processuais que determinam as formas e modalidades de produção da prova e respectivas sanções, já as provas ilícitas têm como consequências sanções previstas especificamente nas normas de direito material violadas.

Contudo, em acertada revisita a estas premissas, ponderam Luiz Guilherme Marinoni e Sérgio Cruz Arenhart ${ }^{32}$ que o critério temporal para a fixação de ilicitude da prova não se justifica, pois, malgrado ocorrida fora do ambiente processual, não há como se vincular necessariamente a violação ao direito material ao momento pré-processual, eis que a lesão à regra de direito material tanto pode ocorrer antes, quanto durante o trâmite do processo, como por exemplo na hipótese de coação de uma testemunha para prestar depoimento em juízo.

Desta forma, certo é que a violação a normas processuais não admite solução uniforme, conquanto estas se submetem a uma gradação quanto a sua relevância, considerada essencial ou não à tutela de direitos fundamentais.

Assim, um meio de prova tanto pode violar simples regras do procedimento probatório, como garantias fundamentais das partes, ainda que de natureza processual, hipótese na qual a gravidade se reveste do mesmo patamar de relevância de uma norma de direito material, reclamando, assim, uma sanção gradual em conformidade com a natureza do direito violado.

Portanto, enquanto a prova advinda de uma ilicitude material é insanável, já que decorre de um procedimento ilícito, a prova decorrente de uma violação de norma processual reclama uma análise detida quanto à sua essencialidade, de sorte que se não o for, submete-se ao regramento de saneabilidade, dentro da instrumentalidade das formas, condicionada a nulidade à demonstração de prejuízo, causalidade e regras preclusivas. De outro lado, a prova emanada de violação de regra processual dotada de caráter essencial, já que lesiva a garantia fundamental, deve ser inadmitida sem maiores questionamentos.

A doutrina se divide em três teorias quanto à admissibilidade dos meios de prova obtidos de modo ilícito no processo: a primeira, que propõe sua irrestrita admissibilidade, sem prejuízo das sanções penais, cíveis e administrativas cabíveis ao infrator; a segunda, defensora de sua inadmissibilidade sem exceções; e a terceira que mitiga a referida vedação em hipóteses excepcionais, que envolvam direitos fundamentais em conflito real, a serem sopesados casuisticamente por meio do princípio da proporcionalidade.

Conforme o registro histórico trazido por Susana Henriques da Costa ${ }^{33}$, antes da promulgação da Constituição Federal de 1988, predominavam na doutrina as teses que defendiam a admissão e, em antítese, a inadmissão dos meios de prova ilícitos em caráter absoluto.

Na ocasião, com prevalência, a doutrina favorável à admissão no processo dos meios de prova obtidos por meio ilícito asseverava que a responsabilidade pela violação ao direito deveria ser apurada sem embargo do aproveitamento dos meios de prova no processo, "se disso puder resultar sentença injusta, vencido o infrator que ficou sem prova e vencedor o verdadeiro ímprobo pela transgressão de normas e preceitos de direito material" 34 .

Em contraposição, a corrente adotada pelos professores da Faculdade de Direito do Largo de São Francisco sustentava a peremptória inadmissibilidade dos meios de prova obtidos de forma ilícita, sendo inclusive objeto da Súmula nº 49 das Mesas de Processo Civil que proclamava que "são processualmente inadmissíveis as provas ilícitas que infringem normas e princípios constitucionais, ainda quando forem relevantes e pertinentes, e mesmo sem cominação processual expressa".

32 MARINONI, Luiz Guilherme. ARENHART, Sérgio Cruz. Prova e convicção. 4 ed. São Paulo: Revista dos Tribunais, 2018. p.292.

33 COSTA, Susana Henriques. Os poderes do juiz na admissibilidade de prova ilícita. Revista de Processo, São Paulo, vol.133/2006, p. 85-120, mar./2006.

34 LIMA, Alcides de Mendonça. A eficácia do meio de prova ilícito no código de processo civil brasileiro. Revista de Processo, São Paulo, vol. 43/1986, p.138-141, jul./set. 1986.

Revista de Direito Brasileira | Florianólopis, SC | v. 25 | n. 10 | p. 366-384 | Jan./Abr. 2020 
Contudo, o advento da Carta Cidadã de 1988, implicou na explícita inserção, no rol dos direitos e garantias fundamentais, da enunciação de serem "inadmissíveis, no processo, as provas obtidas por meios ilícitos" (art. $5^{\circ}$, inciso LVI), momento no qual a controvérsia migrou da existência para a natureza de tal vedação, ganhando força o embate entre as teorias restritiva e mitigada, para as quais esta vedação teria, respectivamente, absoluto e relativo.

Nesta linha, posicionando-se no sentido do caráter absoluto da referida vedação, Luis Roberto Barroso ${ }^{35}$ glosou que houve na espécie uma opção do texto constitucional, que retirou a matéria de qualquer discricionariedade do julgador, elegendo a segurança das relações sociais ao proscrever a prova ilícita.

Em sentido diverso, clássico trabalho de José Carlos Barbosa Moreira ${ }^{36}$ asseverou o caráter instrumental e relativo dos princípios, dentre os quais, inserido o da vedação à admissibilidade da prova ilícita, contraposto ao direito fundamental à prova e a irrazoabilidade de sobreposição abstrata e defendeu a necessidade de deixar ao aplicador da norma uma margem de flexibilidade, de modo a propiciar uma atenta ponderação comparativa dos interesses em jogo no caso concreto.

Pertinente o registro de que a teoria intermediária constava da redação original do anteprojeto do CPC/2015 elaborada pela comissão de juristas, na qual o art.257 - hoje 369, ao tratar do direito das partes ao emprego dos meios de prova legais e moralmente legítimos, continha parágrafo único que previa que a inadmissibilidade das provas obtidas por meio ilícito seria "apreciada pelo juiz à luz da ponderação dos princípios e dos direitos fundamentais envolvidos", sendo, contudo, objeto de veto ainda nas deliberações do Senado Federal por meio da Emenda $\mathrm{n}^{\circ}$ 30 , ao fundamento de que o haveria afrontaria a constituição da república. ${ }^{37}$

Malgrado a supressão do dispositivo em testilha, entende-se que admissão regrada da prova ilícita a luz do postulado da proporcionalidade se coaduna com o texto constitucional.

Com efeito, acertado o escólio de Luiz Guilherme Marinoni e Sérgio Cruz Arenhart ${ }^{38}$ quanto a configurar o inciso XII do art. $5^{\circ}$ da Constituição Federal não meio de tutela dos direitos materiais violados pela obtenção dos meios de prova ilícitos (pois disso já se ocupa a lei material), mas sim de manifestação apriorística da opção por uma consequência acessória, ensejadora de uma proteção extra da norma de direito material em detrimento da descoberta da verdade, de modo que, em acréscimo às sanções pelo ato ilícito, o meio de prova dele advindo é, também, inadmissível em um eventual processo.

Contudo, não se pode descurar da franca distinção de regime jurídico entre o processo civil e o processo penal, posto como, conquanto neste o peso dos interesses em conflito já foi valorado em abstrato, com a prevalência do direito de liberdade à luz da presunção de inocência, direito ao silêncio e proscrição dos meios de prova ilícitos, salvo em benefício do réu, o processo civil se destina à tutela de direitos absolutamente heterogêneos, de modo que "a norma do art. $5^{\circ}$, LVI da CF pode ser conjugada com a opção do processo penal, mas quando pensada em face do processo civil, apenas pode ser ligar a uma falta de opção, ou melhor, à necessidade de que essa opção seja feita diante do caso concreto". 39

Isso justifica que, em adendo à disciplina abstrata que veda aprioristicamente a admissão de tais meios de prova no processo (aí contemplado o de natureza civil), seja realizada uma nova ponderação, entre o direito fundamental que se busca tutelar por meio do processo e aquele violado

35 BARROSO, Luis Roberto. A viagem redonda: habeas-data, direitos constitucionais e as provas ilícitas. Revista de Direito Administrativo, São Paulo, vol. 213/1998, p. 149-163, jul./set. 1998.

36 BARBOSA MOREIRA, José Carlos. A constituição e as provas ilicitamente obtidas. Revista dos Tribunais, vol. 84/1996, p.144-155, out./dez./1996.

37 NETO, Elias Marques de Medeiros. O princípio da proibição da prova ilícita e o projeto de um novo código de processo civil. Revista do Instituto dos Advogados de São Paulo, São Paulo, vol. 30/2012, pág. 135-156, jul.-dez./2012.

38 MARINONI, Luiz Guilherme. ARENHART, Sérgio Cruz. Prova e convicção. 4 ed. São Paulo: Revista dos Tribunais, 2018 p.297.

39 Idem, p.297.

Revista de Direito Brasileira | Florianólopis, SC | v. 25 | n. 10 | p. 366-384 | Jan./Abr. 2020 
para a obtenção do meio de prova, com lastro no postulado da proporcionalidade, que reúne em tais situações, conforme Nivia Aparecida de Souza Azenha ${ }^{40}$, sob a visão do texto constitucional a ilicitude material e a inadmissibilidade da prova.

Tal cotejo possibilita, em hipóteses excepcionais, quando a vedação aos meios de prova ilícitos ensejar distorções ou resultados desproporcionais, injustos ou repugnantes, ao julgador a escolha de um caminho mais justo entre fulminar a prova ilícita ou admiti-la, a ensejar, em Eduardo $\mathrm{Cambi}^{41}$, "uma convivência harmônica dos diversos direitos fundamentais, obtendo resultados socialmente mais legítimos".

Por fim, malgrado o reconhecimento de que a aplicação do referido postulado, através da ponderação, de forma a possibilitar a admissão ocasional dos meios de prova obtidos de forma ilícita contribui para a construção de decisões tendencialmente justas, é inegável que esta não deve corresponder a um comando ambíguo ou indeterminado ${ }^{42}$, ensejador de arbítrio, de modo que reclama uma fundamentação racional.

Nesta toada, a racionalidade da fundamentação se liga à ser a decisão passível de reconstituição, controle e legitimação, de forma que seja possível "reconstruir e prever a probabilidade e o senso comum" do raciocínio. ${ }^{43}$

Desta forma, certo é que o Código de 2015 traz expressiva contribuição para a matéria em estudo ao fixar critérios para a fundamentação adequada na decisão judicial que adota o aludido método ponderativo.

\section{DA TÉCNICA DE PONDERAÇÃO NO CPC/2015 (ART.489, § 2 ${ }^{\circ}$ ) E SUA APLICAÇÃO NA HIPÓTESE DE EXCEPCIONAL ADMISSÃO DOS MEIOS DE PROVA ILÍCITOS}

A adequada motivação das decisões judiciais foi objeto de preocupação do Constituinte originário, que estabeleceu ao tratar do regramento do Poder Judiciário que todos seus julgamentos "serão públicos, e fundamentadas todas as decisões, sob pena de nulidade". (art. 93, IX da CF/88).

Nesta senda, o Código de Processo Civil de 2015 aprimorou os contornos da exigência constitucional, tecendo em minúcias os rígidos critérios para que se repute fundamentado (e, por conseguinte, válido) o pronunciamento jurisdicional por meio do seu art.489, cuja técnica foi recentemente incorporada ipsi litteris ao Código de Processo Penal. ${ }^{44}$

Desta forma, em adição aos requisitos estruturais de relatório, fundamentação e dispositivo, previu o CPC/15 que a decisão deve adotar uma motivação individualizada para o caso em exame, ao explicar a relação dos fatos com o preceito normativo aplicado; o motivo concreto da aplicação de conceitos jurídicos indeterminados; enfrentar todos os argumentos deduzidos e capazes de, em tese, infirmar a conclusão do julgador e identificar ratio decidendi dos precedentes suscitados ou aplicáveis à espécie, enfrentando eventual hipótese de distinção e sua pertinência com o quadro fático da espécie. ${ }^{45}$

Percebe-se que tal plêiade de condicionantes da validade da decisão judicial é atribuível claramente ao redimensionamento do papel do juiz ${ }^{46}$ e representa o "ápice da democracia no

40 AZENHA, Nívia Aparecida de Souza. Prova ilícita no processo civil. Curitiba: Juruá, 2011. p. 135.

41 CAMBI, Eduardo. Curso de direito probatório. Curitiba: Juruá, 2014. p.99.

42 REICHELT, Luis Alberto. A inadmissibilidade das provas ilícitas na perspectiva do direito ao processo justo. Revista de Processo, São Paulo, vol. 228/2014, p.99-122, fev./2014.

43 BRASIL JR, Samuel Meira. Justiça, direito e processo: a argumentação e o direito processual de resultados justos. São Paulo: Atlas, 2007. p. 106.

44 Vide art.315, $\S 2^{\circ}$ do CPP com a redação conferida pela lei 13.964/19.

45 SCALBRIN, Felipe. SANTANNA, Gustavo. A legitimação pela fundamentação: anotações ao art. $489, \S 1^{\circ}$ e $\S$ $2^{\circ}$ do novo código de processo civil. Revista de Processo, São Paulo, vol. 255/2016, p. 17-40, mai./2016.

46 "O juiz tem seu papel redimensionado, assumindo uma dupla posição: mostra-se paritário na condução do processo, no diálogo processual, sendo, contudo, assimétrico no quando da decisão da causa". MITIDIERO, Daniel. Colaboração no processo civil: pressupostos sociais, lógicos e éticos. São Paulo: Revista dos Tribunais, 2009. p.102.

Revista de Direito Brasileira | Florianólopis, SC | v. 25 | n. 10 | p. 366-384 | Jan./Abr. 2020 
processo", conferindo-lhe legitimidade social, porquanto resultado de diversas discussões travadas diretamente entre os sujeitos interessados. ${ }^{47}$

Indo além, pronunciou no $\S 2^{\circ}$ do art.489 que "no caso de colisão entre normas, o juiz deve justificar o objeto e os critérios gerais da ponderação efetuada, enunciando as razões que autorizam a interferência na norma afastada e as premissas fáticas que fundamentam a conclusão".

Cuida-se dentro da técnica legislativa uma metanorma ou norma de segundo grau que, dentro da função de conferir interpretação e aplicação às demais, inseriu no âmbito infraconstitucional o postulado da ponderação como plausível solução para a hipótese em que diferentes enunciados normativos apontem para soluções diversas ou até opostas, no que o código chamou de colisão de normas. ${ }^{48}$

A terminologia adotada enseja justificadas críticas de Leonardo de Faria Duarte ${ }^{49}$, que pontua que, ao que se infere, o vocábulo "norma" incidiria em equívoco, já que "aludiu o legislador à solução de normas-princípio de matriz Alexyana", sendo sua lógica inaplicável, pois a conflitos envolvendo normas-regras, passíveis de outros critérios de solução de antinomias.

Assevera, ademais, que a ordem dos atos no procedimento do dispositivo, que lega por último a indicação das premissas fáticas na fundamentação, ensejaria a subversão da ordem do raciocínio da decisão judicial, passando a impressão de que inicialmente seria tomada a decisão, para, então, serem buscados os substratos fáticos.

Contudo, certo é que com a necessária exegese quanto ao caráter sugestivo da ordem de operações no procedimento de ponderação, e se devidamente aplicado, o dispositivo contribui para a justificação adequada das decisões que tratam de normas principiológicas, trazendo "uma certa racionalização da aplicação da teoria da proporcionalidade, através da técnica da ponderação, evitando-se, assim, o tão temido, porém reiterado decisionismo judicial."50

Nesta toada, percebe-se que a questão pertinente à admissão casuística da prova ilícita no âmbito do processo civil contempla uma colisão entre duas normas-princípio: de um lado a explícita no texto constitucional que estabelece a vedação à sua admissibilidade e, do outro, a de porte implícito $^{51}$ que a esta contrapõe o direito das partes e dever do juízo de proceder à ampla produção da prova relevante para o descortinamento dos fatos, e de conferir efetividade aos direitos submetidos a tutela jurisdicional.

Disso emerge que o $\S 2^{\circ}$ do art. 489 do CPC/15 tem muito a contribuir, propiciando a realização de uma ponderação adequada a luz do postulado normativo da proporcionalidade.

Nesta ordem de ideias, conforme escólio de Samuel Meira Brasil Jr. ${ }^{52}$ reputa-se a proporcionalidade como postulado normativo pois consiste em proposição que, malgrado não evidente, é aceita sem prova, representa um controle sobre a aplicação de uma regra ao concretizar um princípio ou, no caso em exame, na relação entre princípios colidentes, através de uma relação

47 FUX, Luiz. BODOART, Bruno. Notas sobre o princípio da motivação e a uniformização da jurisprudência no novo código de processo civil à luz da análise econômica do direito. Revista de Processo, São Paulo, vol. 269/2017, p.421-432, jul./2017.

48 MARINONI, Luiz Guilherme. ARENHART, Sérgio Cruz. MITIDIERO, Daniel. Curso de processo civil, volume 02, 3 ed. São Paulo: Revista dos Tribunais, 2017. p.459.

49 DUARTE, Leonardo de Faria. Ponderações sobre a ponderação - o § $2^{\circ}$ do art.489 do novo código de processo civil. In: FILHO, Antônio Carvalho. JÚNIOR, Herval Sampaio (coord). Os juízes e o novo CPC. Salvador: JusPodivm, 2017. p.281-283.

50 BRAGA E SILVA, Bernardo. A garantia da fundamentação das decisões judiciais e o novo código de processo civil: o caráter didático dos $\S \S 1^{\circ}$ e $2^{\circ}$ do artigo 489 do NCPC. In: CARNEIRO, Paulo Cezar Pinheiro. GRECO, Leonardo. PINHO, Humberto Dalla Bernardina de. (coord). Inovações do código de processo civil de 2015. Rio de Janeiro: GZ Editora, 2017. p.329.

51 GÓES, Gisele Santos Fernandes. Cotejo entre o direito à prova e a proibição de provas obtidas por meios ilícitos. In: FUX. Luiz. NERY JR. Nelson. WAMBIER. Teresa Arruda Alvim (coord). Processo e constituição: estudos em homenagem ao Professor José Carlos Barbosa Moreira. São Paulo: Revista dos Tribunais, 2006. p.953.

52 BRASIL JR, Samuel Meira. Justiça, direito e processo: a argumentação e o direito processual de resultados justos. São Paulo: Atlas, 2007. p.96-97.

Revista de Direito Brasileira | Florianólopis, SC | v. 25 | n. 10 | p. 366-384 | Jan./Abr. 2020 
meio-fim, de modo a estabelecer o alcance ideal de cada princípio, de sorte que na aplicação de uma regra jurídica, o postulado da proporcionalidade deve ser observado para evitar que os efeitos de um princípio normativo sejam excessivamente afastados.

Desta forma, revisitada a lição de Luis Alberto Reichelt quanto aos quatro aspectos eminentes das deliberações sobre os meios de prova (admissibilidade; relevância; procedimento para sua produção; e valoração) $)^{53}$, sendo, de ordinário, proferidos em ordem logicamente sucessiva, certo é que usualmente a questão concernente a se o meio de prova é ou não admissível precede qualquer indagação quanto a sua relevância para o esclarecimento dos fatos, de modo que apenas se perquire a idoneidade (relevância) de meios previamente reputados cabíveis, conquanto em conformidade com os ditames legais.

Entretanto, em determinadas situações, após a constatação de que o meio de prova, conquanto eivado de ilicitude, é, por conseguinte, a priori, inadmissível, a realização de um procedimento de ponderação pode conduzir ao excepcional afastamento da interdição, quando verificado que os efeitos da proscrição da prova ilícita são mais deletérios que os decorrentes de sua admissão, tendo por fundamento a proporcionalidade, aferida pela técnica da ponderação.

Nesta linha, leciona Luis Roberto Barroso que a aludida técnica contempla três etapas: a identificação das normas relevantes para a solução do caso e dos conflitos impassíveis de solução pela subsunção; o exame dos fatos, circunstâncias concretas do caso e sua interação com os elementos normativos; e, por fim, a escolha, à luz do exame conjunto dos grupos de normas e sua repercussão concreta, como forma de propiciar a identificação dos pesos a serem atribuídos aos elementos em contenda, de modo a se identificar o que deva preponderar e em qual intensidade, tendo como fio condutor a proporcionalidade como princípio. ${ }^{54}$

Ao magistrado assim fazê-lo, a decisão se revestirá da racionalidade ínsita à possibilidade de reconstrução do caminho trilhado, com a identificação dos pesos atribuídos aos argumentos, o que prescinde da adoção de fórmulas matemáticas conforme sistematizado por Robert Alexy, sendo alcançado pela indicação, por intermédio da argumentação, da forma como o sopesamento foi realizado pelo julgador, explicitando a qual elemento foi atribuído peso preponderante, do que deflui a possibilidade de controle de tal aspecto da decisão judicial. ${ }^{55}$

Percebe-se claramente a identidade entre as fases do procedimento de ponderação estabelecidos pela doutrina e as etapas identificadas no $\S 2^{\circ}$ do art. 489 do CPC/15, eis que prenuncia este as fases de indicação do objeto da ponderação (princípios em colisão); identificação das premissas fáticas (exame dos fatos); e dos critérios da ponderação efetuada, com as razões que autorizaram a interferência no princípio afastado (escolha conforme a atribuição de pesos os elementos em disputa).

Perceptível que o referido procedimento decisório contempla a adoção de opções valorativas, transcendendo o rigor lógico-dedutivo tradicional, é inquestionável, conforme assevera

53 REICHELT, Luis Alberto. Direito fundamental à prova e os poderes instrutórios do juiz. Revista de Processo, São Paulo, vol. 281/2018, p.171-185, jul./2018.

54 BARROSO, Luis Roberto. Curso de direito constitucional contemporâneo: os conceitos fundamentais e a construção do novo modelo. 7. ed. São Paulo: Saraiva, 2018. p.378-380.

55 "A ponderação em uma decisão judicial, entretanto, não é feita de modo formal, como sugerido por Alexy. O juiz não fará um cálculo matemático para verificar as razões que justificam a decisão. Apesar de sua grande importância acadêmica - no estudo de um método formal para a ponderação - não podemos excluir uma ponderação feita de modo informal, com a utilização de uma linguagem natural. Não se exige, e nem mesmo seria admissível, que o juiz utilizasse uma fórmula numérica para justificar sua decisão. A reconstrução formal de Alexy tem por finalidade de indicar um método, especificando as variáveis que devem ser ponderadas. Contudo, é plenamente possível utilizar o método de ponderação, sem referência a números. Apenas indicando, por intermédio de argumentos, como a ponderação foi feita pelo julgador, a qual elemento foi atribuído maior peso etc. Com base nessas informações - que, como podemos observar, é o conteúdo da própria justificação - é possível controlar a decisão judicial, muito embora ainda não se possa prevê-la. A previsibilidade somente existe nas hipóteses já decididas e já controladas. Porém, nesse caso haverá uma norma jurídica legal ou jurisprudencial!’.BRASIL JR, Samuel Meira. Justiça, direito e processo: a argumentação e o direito processual de resultados justos. São Paulo: Atlas, 2007. p.109-111.

Revista de Direito Brasileira | Florianólopis, SC | v. 25 | n. 10 | p. 366-384 | Jan./Abr. 2020 
Lúcio Grassi de Gouveia ${ }^{56}$ o caráter curial da participação das partes por meio do seu aporte argumentativo, como forma legitimadora.

Destarte, quanto às balizas para o objeto de estudo, vislumbra-se que à luz do postulado da proporcionalidade, o cabimento excepcional da prova ilícita deve atentar para a análise de sua adequação, necessidade e proporcionalidade strictu sensu.

Assim, inicialmente, deve ser perquirido dialogicamente se os meio de prova ilícito se reveste de adequação ou idoneidade aos fins que almeja tutelados por este (proteção do direito submetido a tutela jurisdicional), ou seja, se tem aptidão para esclarecer fato relevante para o julgamento do processo a partir de um critério negativo. ${ }^{57}$

Portanto, se a proscrição dos meios de prova ilícitos limita a plena de reconstituição dos fatos no ambiente do processo e, por consequência, o alcance da verdade possível, finalidade intrínseca da instrução processual, e conquanto não representa esta um fim em si, mas uma forma de proteção de bens jurídicos ${ }^{58}$, o meio de prova será reputado adequado, de forma a se analisar sua excepcional admissão quando se revelar necessário e útil no plano hipotético para a tutela dos direitos fundamentais postos a apreciação.

Lado outro, revelando-se inadequado, conquanto despido de utilidade ou relevância, o meio de prova deve receber o mesmo destino do meio lícito inadequado, qual seja, o indeferimento dentro da utilização dos poderes instrutórios do Juiz (art.370, paragrafo único do CPC/2015), ocupando-se a fundamentação de explicitar a impertinência do meio de prova, que, por si só, já ilide sua admissibilidade, sendo, para tal jaez, irrelevante sua ilicitude.

Ultrapassado o filtro inicial, a deliberação prossegue com a análise da necessidade do meio de prova ilícito, ocasião na qual, atentando-se à vedação de excesso, deve ser perquirida se a excepcional admissibilidade deste é, dentre as alternativas idôneas, a menos gravosa para o alcance da tutela dos direitos fundamentais em juízo, notadamente quanto a se existe a possibilidade de esclarecimento dos fatos relevantes por meio alternativo de prova reputado lícito, que promova igualmente o fim e com restrição em menor medida dos direitos fundamentais afetados colateralmente $^{59}$, hipótese em que, identificado meio lícito e praticável, ainda que mais oneroso às partes, deverá ser este privilegiado, afastando-se aquele despojado de licitude.

Portanto, somente é justificada a opção pelo meio obtido de maneira ilícita, se não houver, em sede de prospectiva, meio alternativo para a averiguação dos fatos, sendo este absolutamente necessário.

56 "Nessa linha de raciocínio, o pensamento jurídico deixa de ser tão-só o analítico-teorético conhecimento (a reprodução) de um direito pressupostamente constituído a que se seguiria uma mera aplicação, para participar ele também na normativa-constituição (da produção) do direito através da sua problemático-concreta e judicativodecisória realização histórica - e enquanto uma tal realização, nesse sentido, exige já uma concretização, já uma integração, já um autônomo desenvolvimento constitutivo do direito positivo, pelo que o juiz participa da criação do Direito. E em tal mister, devem os tribunais contar com a cooperação dos maiores interessados no processo decisório, as partes, que através de sua atuação assistida pelo juiz ou tribunal poderão interferir decisivamente na formação do convencimento dos julgadores e nos destinos de um processo que pretenda ser democrático e igualitário.”. GOUVEIA, Lúcio Grassi de. A função legitimadora do princípio da cooperação interssubjetiva no processo civil brasileiro. Revista de Processo, São Paulo, vol.172/2009, p.32-53, jun./2009.

57 “O aspecto da otimização presente na máxima da adequação não aponta para um ponto máximo. Essa máxima tem, na verdade, a natureza de um critério negativo. Ela elimina meios não adequados. Um tal critério negativo não determina tudo, mas exclui algumas coisas. Nesse sentido, ele ajusta-se à ideia de uma ordem-moldura. Como elemento de uma ordem como essa, el exclui algumas coisas - a saber: aquilo que não é adequado - sem, com isso, determinar tudo". ALEXY, Robert. Teoria dos direitos fundamentais. tradução de Virgílio Afonso da Silva. 2. ed São Paulo: Malheiros Editores, 2017. p.590.

58 REICHELT, Luis Alberto. A inadmissibilidade das provas ilícitas na perspectiva do direito ao processo justo. Revista de Processo, São Paulo, vol. 228/2014, p.99-122, fev./2014.

59 ÀVILA, Humberto. Teoria dos princípios: da definição a aplicação dos princípios jurídicos. 18 ed. São Paulo: Malheiros Editores, 2018. p.217.

Revista de Direito Brasileira | Florianólopis, SC | v. 25 | n. 10 | p. 366-384 | Jan./Abr. 2020 
Por derradeiro, a análise é concluída com o cotejo da proporcionalidade em sentido estrito, a partir do equacionamento entre as vantagens e desvantagens do afastamento casuístico da vedação aos meios de prova ilícitos na hipótese dos autos.

Neste diapasão, constando-se que a solução da controvérsia ensejará o sacrifício de um dos bens jurídicos em conflito (direito material violado na produção do meio de prova ilícito $\mathrm{x}$ direito a ser tutelado por meio do processo que reclama o esclarecimento fático pela utilização do aludido meio de prova), deve-se valorar em que medida se deve dar tal lesão a partir do seu resultado, sendo inadmitido o sacrifício de bem jurídico para a tutela de outro com menor peso. ${ }^{60}$

Portanto, deve-se atentar-se para o objeto da tutela jurisdicional, que apresenta absoluta heterogeneidade no processo civil, que pode contemplar desde direitos patrimoniais disponíveis a interesses de incapazes, como crianças e adolescentes em relação aos quais vige a proteção integral $^{61}$ ou de grupos vulneráveis, bem como interesses transindividuais como a proteção ao meio ambiente, probidade administrativa ou erário.

De outro lado, o espectro do direito material violado para a produção do meio de prova ilícito também contempla variedade, podendo ir desde a intimidade das partes, seu sigilo profissional, até a integridade física e vedação à tortura ou práticas degradantes.

Portanto, da contraposição entre estes dois direitos, e sob o diálogo cooperativo, deve se operar a decisão que os equaciona, de modo a garantir a utilização dos meios adequados estritamente. $^{62}$

\section{CONCLUSÕES}

A prova se afigura como direito fundamental de porte implícito extraído do contraditório e ampla defesa, e componente da tendencial justiça da decisão, não devendo sofrer limitações

60 "Por fim, o postulado da proporcionalidade em sentido estrito (Grundsatz der Verhaltnismassigkeit im engern Sinne) envolve a própria ponderação dos bens em colisão. Segundo este critério, não se admite o sacrifício de um bem jurídico como meio para se atingir um fim que tenha menor peso do que o bem jurídico sacrificado. Assim, deve ser realizada uma ponderação entre duas finalidades, ou dois princípios jurídicos. O Prof. Alexy define a proporcionalidade em sentido estrito no seguinte contexto: quanto maior for a interferência em um princípio $\mathrm{P} 2$, mais importante deve ser a realização do outro princípio, digamos P1. Como exemplo, poderíamos imaginar o confinamento de um portador de AIDS por toda a vida, como forma de evitar a disseminação da doença, promovendo o princípio que protege a saúde pública. Mesmo supondo que esta medida fosse adequada (com o confinamento evita-se a disseminação da doença) e necessário (não haveria outro meio mais brando de evitar a disseminação da doença), ainda assim seria completamente desproporcional, pois causaria uma interferência no princípio da dignidade da pessoa humana em grau absolutamente intolerável. A medida visa a uma consequência que não pode ser qualificada como mais importante que o outro princípio". BRASIL JR, Samuel Meira. Justiça, direito e processo: a argumentação e o direito processual de resultados justos. São Paulo: Atlas, 2007. p.100.

61 "É de se admitir, assim, pois, que as provas mecânicas ou eletrônicas obtidas por meio de gravações de áudio por meio de aparelhos celulares, secretárias eletrônicas ou sistemas de monitoramento; as filmagens e postagens de conteúdos em redes sociais; a troca de e-mails e de textos escritos em chats eletrônicos, inclusive WhatsApp e assemelhados possam ser utilizados em Juízo sempre que sirvam para resguardar o sublime direito da criança de ver preservada sua higidez física e mental e assegurados sua proteção integral e melhor interesse em prioridade absoluta. O fio da balança que se coloca entre a privacidade das relações familiares e a proteção integral da criança deve pender em prol desta última, especialmente nas hipóteses de grave violação aos direitos infantojuvenis como os que se destacam da prática da alienação parental. Não se nega que a privacidade, a intimidade, a honra, a imagem e o sigilo de correspondência sejam direitos fundamentais. Todavia, não podem ser ilimitados. De fato, dentro da teoria da colisão de direitos e do princípio da cedência recíproca, nada impede que o absolutismo da garantia à privacidade, intimidade, honra e imagem ceda o passo à razoabilidade em prol da preservação do direito da criança à saúde física $\mathrm{e}$ mental e a uma convivência familiar íntegra e cuidadosa." AURELLI, Arlete Inês. LEITE, Rita de Cássia Curvo. Admissibilidade da "prova ilícita" em demandas envolvendo interesses de crianças. Revista de Processo, São Paulo, vol. 303/2020, p.259-290, mai.2020.

62 ANDRADE, Adalberto Guedes Xavier de. A aplicabilidade do princípio da inadmissibilidade das provas obtidas por meio ilícito no processo civil. Revista de Processo, São Paulo, vol. 126/2005, p. 219-245, ago/2005.

Revista de Direito Brasileira | Florianólopis, SC | v. 25 | n. 10 | p. 366-384 | Jan./Abr. 2020 
injustificadas, sendo a valoração objeto de ponderação de proporcionalidade na forma do art. 370 do $\mathrm{CPC} / 2015$.

Os poderes instrutórios do juiz são ressignificados no processo contemporâneo à luz da norma fundamental da cooperação (art. $\left.6^{\circ}, \mathrm{CPC} / 2015\right)$, que implica em uma atuação equilibrada e cooperativa entre partes e juiz, com relevante projeção na fase instrutória do procedimento, sendo a iniciativa probatória do magistrado concreto ato contributivo para o alcance de uma decisão de mérito justa e efetiva em tempo razoável.

A ponderação entre o direito fundamental que se busca tutelar por meio do processo e aquele violado para a obtenção do meio de prova possibilita a excepcional admissibilidade de meios de prova ilícitos no processo civil.

A racionalidade e legitimidade democrática da decisão que admite a utilização de meio de prova ilícito reclama fundamentação idônea, por meio do procedimento de ponderação previsto no $\S 2^{\circ}$ do art.489 do CPC/2015.

Inicialmente deve-se deliberar sobre a identificação do objeto da ponderação, concernente aos princípios em colisão (direito à prova e vedação aos meios de prova ilícitos) em seus contornos concretos.

Em seguida, deve-se proceder ao exame pormenorizado dos fatos, concernentes em especial à adequação do meio de prova ilícito para o esclarecimento de fato controverso e relevante e à sua necessidade, dada a inexistência de alternativa.

E, por fim, deve-se indicar a proporcionalidade estrita da escolha, por meio das razões que autorizam a interferência no princípio afastado, por meio de uma escolha com a atribuição de pesos aos elementos em disputa, atenta à heterogeneidade do objeto de tutela pelo processo civil e variada gradação de violação aos direitos fundamentais para a colheita dos meios de prova ilícitos.

A decisão reclama o prévio e efetivo diálogo com as partes, às quais deve ser oportunizado, independente da iniciativa probatória, o debate sobre o preenchimento dos requisitos para a excepcional admissão da prova ilícita.

\section{REFERÊNCIAS}

ABELHA, Marcelo. Manual de direito processual civil. 6. ed. Rio de Janeiro: Forense, 2016

ALEXY, Robert. Teoria dos direitos fundamentais. Tradução de Virgílio Afonso da Silva. $2^{\mathrm{a}}$ ed. $5^{\text {a }}$ tir. São Paulo: Malheiros, 2017.

ANDRADE, Adalberto Guedes Xavier de. A aplicabilidade do princípio da inadmissibilidade das provas obtidas por meio ilícito no processo civil. Revista de Processo, vol. 126/2005, p . 219 245 , ago/2005.

AURELLI, Arlete Inês. LEITE, Rita de Cássia Curvo. Admissibilidade da "prova ilícita" em demandas envolvendo interesses de crianças. Revista de Processo, São Paulo, vol. 303/2020, p.259-290, mai.2020.

ÀVILA, Humberto. Teoria dos princípios: da definição à aplicação dos princípios jurídicos. 18. ed. São Paulo: Malheiros Editores, 2018.

AVOLIO, Luiz Francisco Torquato. Provas ilícitas: interceptações telefônicas, ambientais e gravações clandestinas. 6 ed. São Paulo: Revista dos Tribunais, 2015. 
AZENHA, Nivia Aparecida de Souza. Prova ilícita no processo civil. $1^{\mathrm{a}}$ ed. $5^{\mathrm{a}}$ reimpr. Curitiba: Juruá, 2011.

BARBOSA MOREIRA, José Carlos. A constituição e as provas ilicitamente obtidas. Revista dos Tribunais, vol. 84/1996, p.144-155, out/dez/1996.

BARBOSA MOREIRA, José Carlos. O juiz e a prova. Revista de Processo, vol.35/1984, p.178184, jul.-set./1984.

BRASIL. Constituição (1988). Constituição da República Federativa do Brasil: promulgada em 5 de outubro de 1988.

BRASIL. Lei 13.105, de 16 de março de 2015. Código de Processo Civil: publicado em 16 de março de 2015.

BRASIL. Decreto-Lei 3.689, de 3 de outubro de 1941. Código de Processo Penal: publicado em 03 de outubro de 1941.

BARROSO, Luís Roberto; BARCELLOS, Ana Paula de. A viagem redonda: habeas-data, direitos constitucionais e as provas ilícitas. Revista Trimestral de Direito Público, n. 24/14, 1998.

BARROSO, Luis Roberto. Curso de direito constitucional contemporâneo: os conceitos fundamentais e a construção do novo modelo. 7 ed. 2t. São Paulo: Saraiva, 2018.

BEDAQUE, José Roberto dos Santos. Garantia da amplitude de produção probatória. In: CRUZ E TUCCI, José Rogério (coord). Garantias Constitucionais do Processo Civil. São Paulo: Revista dos Tribunais, 1999.

BEDAQUE, José Roberto dos Santos. Poderes instrutórios do juiz. 7 ed. São Paulo: Revista dos Tribunais, 2013.

BRAGA E SILVA, Bernardo. A garantia da fundamentação das decisões judiciais e o novo código de processo civil: o caráter didático dos $\S \S 1^{\circ}$ e $2^{\circ}$ do artigo 489 do NCPC. In:

CARNEIRO, Paulo Cezar Pinheiro. GRECO, Leonardo. PINHO, Humberto Dalla Bernardina de. Inovações do código de processo civil de 2015. Rio de Janeiro: GZ Editora, p.305-332, 2016.

BRASIL JR, Samuel Meira. Justiça, direito e processo: a argumentação e o direito processual de resultados justos. São Paulo. Atlas, 2007.

CABRAL, Trícia Navarro Xavier. Limites da liberdade processual. Indaituba: Foco, 2019.

CABRAL, Trícia Navarro Xavier. Poderes instrutórios do juiz no processo de conhecimento. Brasília: Gazeta Jurídica, 2012.

CÂMARA, Alexandre Freitas. Poderes instrutórios do juiz e o processo civil democrático. Revista de Processo, vol. 153/2017. p.33-46, nov./2007. 
CAMBI, Eduardo. Curso de direito probatório. Curitiba: Juruá, 2014.

COSTA. Susana Henrique da. Os Poderes do Juiz na Admissibilidade de Prova Ilícita. In: Revista de Processo, vol. 133/2006, p. 85-120, mar/2006.

DEXHEIMER, Vanessa Grazziotin. Atuação do juiz na condução do processo civil no estado constitucional. In: MITIDIERO, Daniel (coord). O processo civil no estado constitucional. Salvador: JusPodivm, p.481-548, 2012.

DIAS, Luciano Souto. Poderes instrutórios do julgador na fase recursal do processo civil: em busca da verdade. Salvador: JusPodivm, 2018.

DORIA, Rogéria Dotti. O Direito à prova e a busca da verdade material. In: NEVES, Daniel Amorim Assumpção (coord). Provas: aspectos atuais do direito probatório, p.324-327, São Paulo: Método, 2009.

DUARTE, Leonardo de Farias. Ponderações sobre a ponderação - o $§ 2^{\circ}$ do art.489 do novo código de processo civil. In: FILHO, Antônio Carvalho. JÚNIOR, Herval Sampaio (coord). Os juízes e o novo CPC. Salvador: JusPodivm, p.281-302, 2017.

FERNANDES, Jorge Luiz Reis. Cooperação: os deveres do juiz e das partes no novo código de processo civil. Belo Horizonte: Letramento/Casa do Direito, 2017.

FUX, Luiz. BODOART, Bruno. Notas sobre o princípio da motivação e a uniformização da jurisprudência no novo código de processo civil à luz da análise econômica do direito. Revista de Processo, vol. 269/2017, p.421-431, jul/2017.

GODINHO, Robson Renault. Reflexões sobre os poderes instrutórios do juiz. In: MACÊDO, Lucas Buril de. PEIXOTO, Ravi. FREIRE, Alexandre. Provas. (Coleção novo CPC doutrina selecionada (Coord Geral Fredie Didier Jr.). Vol. 3.2 ed, Salvador: JusPodivm, p.343-36, 2016.

GÓES, Gisele Santos Fernandes. Cotejo entre o direito à prova e a proibição de provas obtidas por meio ilícito. In: FUX, Luiz. NERY JR, Nelson. WAMBIER, Teresa Arruda Alvin. Processo e constituição: estudos em homenagem ao professor José Carlos Barbosa Moreira. São Paulo: Revista dos Tribunais, p.952-958, 2006.

GOUVEIA, Lúcio Grassi de. A função legitimadora do princípio da cooperação interssubjetiva no processo civil brasileiro. Revista de Processo, São Paulo, vol.172/2009, p.32-53, jun./2009.

GRINOVER, Ada Pellegrini. As Provas ilícitas na constituição. In: Processo em evolução. Rio de Janeiro. Forense Universitária. 1996.

LIMA, Alcides de Mendonça. A Eficácia do Meio de Prova Ilícito no Código de Processo Civil Brasileiro. In. Revista de Processo, vol. 43/1986, p.138-141, jul/set 1986. 
MARINONI, Luiz Guilherme; ARENHART, Sérgio Cruz e MITIDIERO, Daniel. Novo curso de processo civil: tutela dos direitos mediante procedimento comum, vol. 2 . 3 ed. São Paulo: Revista dos Tribunais, 2017.

MARINONI, Luiz Guilherme. ARENHART, Sérgio Cruz. MITIDIERO, Daniel. Novo curso de processo civil: teoria do processo civil. vol. 1. 3 ed. São Paulo: Revista dos Tribunais, 2017.

MARINONI, Luiz Guilherme. ARENHART, Sérgio Cruz. Prova e convicção. 3 ed. São Paulo: Revista dos Tribunais, 2018.

MEDEIROS NETO. Elias Marques. O Princípio da Proibição da Prova Ilícita e o Projeto de um Novo Código de Processo Civil. Revista do Instituto dos Advogados de São Paulo, vol. 30/2012, pág. 135-156, jul.-dez,/2012.

MITIDIERO, Daniel. Colaboração no processo civil. pressupostos sociais, lógicos e éticos. São Paulo: Revista dos Tribunais, 2009.

MITIDIERO. Daniel. A colaboração como norma fundamental no novo processo civil brasileiro. Revista do Advogado: o novo código de processo civil. São Paulo, n. 126, p.47-51, 2015.

MOUSSALEM, Tarek Moysés. Revogação em matéria tributária. São Paulo: Noeses,2005.

PIMENTA, Henrique de Souza. A cooperação no CPC-2015: colaboração, comparticipação ou cooperação para o processo? Dissertação (Mestrado em Direito Processual) - Universidade Federal do Espirito Santo, Centro de Ciências Jurídicas e Econômicas, 2018.

PORTO, Sérgio Gilberto. Processo civil contemporâneo: elementos, ideologia e perspectivas. Salvador: JusPodivim, 2018.

REICHELT, Luis Alberto. A inadmissibilidade das provas ilícitas na perspectiva do direito ao processo justo. Revista de Processo, vol. 228, p.99-122., fev/2014.

REICHELT, Luis Alberto. A prova no direito processual civil. Porto Alegre: Livraria do Advogado, 2009.

REICHELT, Luis Alberto. O direito fundamental à prova e os poderes instrutórios do juiz. Revista de Processo, vol. 281/2018, p. 171-185, jul/2018.

SCALBRIN, Felipe e SANTANNA, Gustavo. A Legitimação pela Fundamentação: Anotações ao art. 489, $\S 1^{\circ}$ e $\S 2^{\circ}$ do Novo Código de Processo Civil. Revista de Processo, vol. 255/2016, p.1740, mai.2016.

SEGUNDO. Hugo de Brito Machado. Os Poderes Instrutórios do Juiz no Novo CPC. In: MACÊDO, Lucas Buril de. PEIXOTO, Ravi. FREIRE, Alexandre. Provas. Coleção novo CPC doutrina selecionada. vol. 3. 2 ed, Salvador: JusPodivm, p.327-340, 2016. 
TARUFFO, Michele. As Verdades Judiciais. tradução de José Teisheiner. In: Ensaios sobre o Processo Civil: escritos sobre processo e justiça. Porto Alegre: Livraria do Advogado, 2017.

TARUFFO, Michele. Uma simples verdade: o juiz e a construção dos fatos. tradução de Vitor de Paula Ramos. São Paulo: Marcial Pons, 2016.

ZANETI JR, Hermes. O princípio da cooperação e o código de processo civil: cooperação para o processo. In: Processo Civil Contemporâneo: Homenagem aos 80 anos do professor Humberto Theodoro Júnior, organização Edgard Audomar Marx Neto [et al.] Rio de Janeiro, Forense, p.142-156, 2018. 